Journal of Early Childhood Care $\&$ Education JECCE

ISSN : 2615-1413 (online)

http://journal2.uad.ac.id/index.php/jecce

\title{
INTERVENSI ANAK USIA DINI PENYANDANG AUTIS
}

(Studi Kasus Pada Anak Autis di Kota Metro Lampung)

Ismet

STKIP PGRI Metro

ismet.unila@gmail.com

Info Artikel

Submitted:

8 Agustus 2018

Accepted:

10 Februari 2019

Published:

15 Maret 2019

\section{Abstrak}

Artikel ini merupakan studi kasus yang memiliki tujuan menggambarkan intervensi pada anak berkebutuhan khusus yaitu autis. Di dalam melaksanakan penelitian penulis mendapatkan informasi dari hasil pengamatan dan wawancara langsung dengan informan yang berkaitan dengan anak seperti orang tua, guru dan terapis. Subjek penelitian adalah seorang anak berkebutuhan khusus yaitu autis yang berusia lima tahun. Dari hasil pengamatan dan wawancara diperoleh informasi bahwa intervensi yang dilakukan terhadap IM dilakukan melalui terapis yaitu terapi prilaku, terapi wicara, terapi bermain, terapi okupasi dan terapi diet. Dari hasil studi kasus ini diketahui bahwa terapi yang diberikan sesungguhnya hanya petunjuk dan awal latihan, selanjutnya orang tua dan guru yang melatih anak untuk berprilaku sehingga anak menjadi mandiri. Setelah dilakukan terapis beberapa aspek perkembangan berkembang dengan baik terutama pada kemandirian dan interaksi sosial dengan lingkungannya. Tetapi harapan yang terlalu besar dari orang tua membuat terapis dan guru merasa kurang nyaman, sebaiknya orang tua tidak menyerahkan begitu saja perubahan prilaku anaknya ke terapis atau sekolah tetapi juga keluarga harus dengan sabar melatih anaknya sebagai tindak lanjut dari konsultasi pada saat dilakukan terapi.

Kata Kunci : anak usia dini, autis, intervensi

\begin{abstract}
This article is a case study that describes the intervention in children with special needs autism. In conducting the research authors obtain information from the results of observation and direct interviews with informants related to children such as parents, teachers and therapists. The subject of study was a child with special needs of five-year-old autism. From the results of observations and interviews obtained information that the interventions made on IM is done through therapist behavioral therapy, speech therapy, play therapy, occupational therapy and diet therapy. From the results of observations and interviews obtained information that the therapy provided is really only the instructions and beginning of the exercise, then parents and teachers who train children to behave so that children become independent. After the therapist performed some aspects of development develop well especially on independence and social interaction with the environment. But too much hope from parents makes the therapist and teacher feel uncomfortable, the parents should not submit their child's behavior change to the therapist or at school but also the family should patiently train their child as a followup of the consultation during the therapy.

Keywords : early childhood, intervention, autism
\end{abstract}

Copyright @ 2019 JECCE, Universitas Ahmad Dahlan

$\triangle$ Alamat korespondensi:

Jl. Ki Hajar Dewantara Banjarejo Batanghari Lampung Timur

HP: o852 69791936 


\section{PENDAHULUAN}

Jumlah anak penderita autis semakin banyak dalam beberapa tahun terakhir ini. Dengan adanya metode diagnosis yang kian berkembang hampir dipastikan anak yang terdeteksi terkena autis akan semakin banyak. Autisme adalah suatu gangguan tumbuh kembang yang rumit menyangkut komunikasi, interaksi sosial, kognisi, dan aktivitas imajinasi. Gejalanya mulai tampak sebelum anak berusia 3 tahun. Bahkan pada autisme pada anak (infantil) gejala sudah ada sejak lahir. Anak baru dapat dikatakan termasuk kategori autisme, bila ia memiliki hambatan perkembangan dalam tiga aspek yakni kualitas kemampuan interaksi sosial dan emosional, kualitas yang kurang dalam kemampuan komunikasi timbal balik, minat yang terbatas disertai gerakan-gerakan berulang tanpa tujuan (Hidayat, 2009)

Berbagai upaya dapat dilakukan untuk membantu anak yang memiliki kebutuhan khusus diantaranya mengembangkan program intervensi yang tepat. Untuk mengembangkan program intervensi ada beberapa hal yang harus diketahui diantaranya diagnosa dan informasi prilaku awal tentang anak dari orang tua dan berbagai ahli dibidang perkembangan anak seperti dokter anak, psikolog, terapis dan lain sebagainya. Informasi tentang tingkah lalu anak di awal ini menjadi semakin penting karena program yang dikembangkan harus bertitik tolak dari berbagai perilaku awal anak, termasuk di antaranya jenis kesulitan yang dihadapi, kemampuan yang dikuasai serta kelebihan dan kekurangan anak dalam bidang tertentu (Soeharso, 2011). Tujuan utama dari penanggulangan atau terapi autis adalah untuk mengurangi gejalagejala yang berkaitan dengan autis dan tekanan yang terjadi di dalam keluarga. Upaya terapi ditujukan untuk meningkatkan kualitas hidup anak autis agar dapat berfungsi di dalam kehidupan sehari-hari secara mandiri (Jamaris, 2014). Terapi yang dilakukan di lembaga pendidikan tidak cukup sebaiknya terapi dilanjutkan di rumah oleh orangorang terdekat. Orang tua memiliki pengaruh yang sangat besar bagi tumbuh kembang anak. Semakin dini usia anak pegaruh orang tua serta orang terdekat yang berada di rumah atau keluarga lainnya semakin besar (Hurlock, 2006), karena lingkungan pertama tempat anak berinteraksi adalah keluarga.

\section{METODE}

Penelitian ini merupakan studi kasus dimana informasi diperoleh menggunakan metode pengamatan dan wawancara langsung menggunakan instrumen observasi. Yang menjadi narasumber tentunya anak tersebut melalui pengamatan selanjutnya peneliti mendapatkan informasi dari orang tua, guru dan terapis. Selain itu peneliti 
menggunakan instrumen CHAT (chelist for autism in toddlers) sebagai landasan menentukan level hambatan perkembangan anak.

Subjek penelitian adalah seorang anak berkebutuhan khusus yaitu autis yang berusia lima tahun bernama IM (inisial). Penelitian ini dilakukan selama kurun waktu tiga bulan. Dari hasil pengamatan dan wawancara diperoleh data bahwa intervensi yang dilakukan terhadap IM dilakukan melalui terapis yaitu terapi prilaku, terapi wicara, terapi bermain, terapi okupasi, terapi diet. Terapi yang intens dilakukan oleh ahlinya "terapis" adalah terapi wicara dan terapi okupasi sedangkan yang lain dilakukan oleh guru, orang tua dan ahli gizi. Terapi wicara dan okupasi dilakukan di klinik sekolah dengan frekuensi satu kali seminggu, lama terapis adalah 2 jam dibagi menjadi dua yaitu untuk anak 90 menit dan untuk orang tua 30 menit. Dalam laporan studi kasus ini akan dijabarkan tentang prosedur intervensi kepada anak berkebutuhan khusus yaitu anak autis.

\section{HASIL DAN PEMBAHASAN}

Hasil pengamatan yang dilakukan peneliti meliputi 5 jenis terapi yaitu terapi prilaku, terapi wicara, terapi bermain, terapi okupasi dan terapi diet dapat dijabarkan sebagai berikut:

1) Terapi perilaku (behavior theraphy)

Terapi perilaku yang dilakukan memiliki tujuan untuk menstimulasi perilaku tumbuh kembang anak yang terhambat serta mengurangi perilaku-perilaku yang tidak wajar guna menggantikannya dengan perilaku wajar sehingga dapat diterima oleh lingkungan terdekat dan masyarakat. Terapi perilaku ini adalah titik awal bagi anak autis yang belum patuh (belum bisa kontak mata dan duduk mandiri) karena program awal terapi perilaku adalah melatih kepatuhan karena kepatuhan ini sangat dibutuhkan saat anak akan diberi stimulasi terapi lainnya seperti fisioterapi, Speech Therapist (terapi wicara), terapi okupasi, karena tanpa kepatuhan ini, terapi yang diikuti akan sulit untuk berhasil.

Tujuan utama dalam melakukan terapi perilaku adalah stimulasi terletak pada pemberian penguatan positif setiap kali anak memberikan respon benar sesuai instruksi atau petunjuk yang diberikan. Tujuan stimulasi ini terutama untuk meningkatkan pemahaman dan kepatuhan anak terhadap aturan. Terapi ini umumnya mendapatkan hasil yang optimal bila dilakukan secara terus menerus, teratur dan konsisten pada anak. Tidak ada hukuman (punishment) dalam terapi ini, akan tetapi bila anak berespons negatif (salah/tidak tepat) atau tidak merespons 
sama sekali maka anak tidak mendapatkan penguatan positif yang ia sukai tersebut. Perlakuan ini diharapkan meningkatkan kemungkinan anak untuk merespons positif dan mengurangi kemungkinan ia merespons negatif (atau tidak merespons) terhadap instruksi yang diberikan.

Terapi yang dilakukan terhadap IM diantaranya melatih IM untuk patuh pada aturan yang ada seperti duduk dengan baik, bersalaman, berbicara dengan berhadap-hadapan "kontak mata" table manner (cara makan dan minum) serta toilet traning. Praktik duduk dengan baik dilakukan IM dengan menyediakan 2 bangku kecil, terapis atau guru mengajak IM untuk duduk seperti yang dilakukan guru. Selanjutnya terapis atau guru mengajak IM berkomunikasi, istilah lainnya ngobrol dengan saling berhadapan dan saling bertatapan.

2) Terapi wicara

Terapi wicara bertujuan untuk melancarkan oral motor agar dapat berbicara lebih baik. Terdapat dua jenis terapi wicara yang diberikan kepada IM yang pertama adalah terapi alat berbicara yaitu dengan memijat dan melatih alat wicara dari pipi, dagu dan lidah. Yang kedua adalah melakukan latihan artikulasi dengan bantuan benda-beda nyata terapis mengajak IM menyebutkan benda tersebut secara berulang-ulang.

3) Terapi bermain

Terapi bermain yaitu terapi oleh guru di sekolah untuk melatih interaksi sosial anak dengan lingkungan melalui permainan. Bermain dengan teman seusianya memiliki manfaat untuk melatih anak berbicara, komunikasi, interaksi sosial serta mengendalikan emosi anak. Dalam hal ini guru membantu anak untuk berinteraksi dengan teknik-teknik tertentu serta menggunakan media yang agar anak menjadi tertarik. Terapi bermain ini bertujuan selain untuk bersosialisasi juga untuk terapi perilaku melalui bermain sesuai aturan. Dari hasil pengamatan sangat sulit mengajak anak autis untuk bermain bersama temannya, mereka cenderung bermain sendiri dengan mainannya, disinilah fungsi guru yaitu mengajak, mengarahkan dan membmbing anak autis untuk mau bermain dan berinteraksi secara kelompok.

4) Terapi okupasi

Terapi ini dilakukan untuk memperbaiki koordinasi dan keterampilan otototot wicara pada anak autis dengan kata lain juga untuk melatih motorik halus anak. Hampir semua anak autis mempunyai keterlambatan dalam perkembangan motorik halus. Latihan-latihan okupasi yang diberikan kepada IM diantaranya adalah memegang pensil dengan cara yang benar, memegang sendok dan menyuap makanan 
kemulutnya, memasangkan kancing, memasukan benda pada tempatnya seperti memasukan pasir/beras ke dalam botol dan lain sebagainya. Dalam hal ini terapi okupasi sangat penting untuk melatih mempergunakan otot halusnya dengan benar.

5) Terapi makanan

Terapi makanan dilakukan memalui diet dikonsultasikan dengan ahli gizi dan dokter anak terlebih dahulu. Untuk IM diet yang dilakukan adalah makan makanan tidak mengandung gluten dan kasein, yang berarti menghindari makanan dan minuman yang mengandung gluten dan kasein. Gluten adalah zat protein yang secara alami terdapat dalam jenis-jenis "rumput" seperti gandum/terigu, havermuth/oat, dan barley. Gluten memberi kekuatan dan kekenyalan pada tepung terigu dan tepung bahan sejenis, sedangkan kasein adalah protein susu. Makanan yang dihindari adalah : a) Makanan yang mengandung gluten, yaitu semua makanan dan minuman yang dibuat dari terigu, havermuth, dan oat misalnya roti, mie, kuekue, biskuit, kue kering, pissa, makaroni, sepageti, tepung bumbu, dan sebagainya; b) Produk-produk lain seperti soda kue, baking soda, kaldu instant, saus tomat dan saus lainnya, serta lada bubuk, mungkin juga menggunakan tepung terigu sebagai bahan campuran. Jadi, perlu hati-hati pemakaiannya. Cermati dan baca label pada kemasannya. c) Makanan sumber kasein, yaitu susu dan hasil olahanya misalnya, es krim, keju, mentega, yogurt, dan makanan yang memiliki campuran dari susu; d) daging, ikan, atau ayam yang diawetkan dan diolah seperti sosis, kornet, nugget, hotdog, sarden, daging asap, ikan asap, dan lainnya. Makan tempe juga tidak dianjurkan bagi anak yang alergi terhadap jamur karena pembuatan tempe menggunakan pembusukan dari jamur ragi. Buah dan sayur yang diawetkan seperti buah dan sayur dalam kaleng sehingga menjadi tidak alamilagi.

Makanan yang baik dikonsumsi bagi anak autis diantaranya adalah a) makanan yang mengandung sumber karbohidrat dipilih yang tidak mengandung gluten, misalnya beras merah, singkong, ubi talas, jagung manis, tepung beras, tapioka, maizena, bihun, soun. b) makanan sumber protein dipilih yang tidak mengandung kasein, misalnya susu kedelai, daging, dan ikan segar tanpa bahan pengawet, unggas, telur, udang, kerang, cumi, tahu, kacang hijau, kacang merah, kacang tolo, kacang mede, kacang kapri dan kacang-kacangan lainnya. Dan c) Sayuran segar seperti bayam, brokoli, labu siam, labu kuning, kangkung, tomat, wortel, timun, dan sebagainya. d) buah-buahan segar seperti mangga, melon, papaya, belimbing, pisang, jambu, jeruk, semangka, dan sebagainya. 
Hasil pengamatan dan wawancara menunjukkan bahwa banyak hasil yang telah dicapai diantaranya dalam perilaku anak mampu mematuhi beberapa aturan seharihari seperti cara duduk yang baik, cara makan yang benar tetapi masih sulit mengatur anak untuk diam dalam satu tempat apalagi dalam waktu lama. Dalam berbicara IM telah mampu menyebutkan beberapa kata dengan artikulasi yang tepat seperti bapak, ibu, makan, buah tetapi sayangnya IM hanya mau berbicara kepada orang-orang tertentu seperti pada terapis atau orang tuanya saja, ia masih jarang mengajak temannya untuk berkomunikasi lebih banyak tindakannya.

Awalnya IM tidak bisa mengontrol motorik halusnya untuk melakukan kegatan sehari-hari tetapi setelah dilakukan terapis IM mampu memegang pensil dan sendok walaupun belum sempurna dan masih membutuhkan bimbingan, IM juga mau di ajak bermain memasukan pasir atau beras ke botol lalu mencocokan gambar dan memang masih harus diarahkan belum bisa mandiri. Hambatan yang dialami dalam pemberian intervensi terhadap anak ini adalah ekpektasi/harapan orang tua yang terlalu tinggi terhadap pekembangan anaknya membuat terapis dan guru merasa tidak nyaman. Orang tua kadang memaksakan anaknya untuk melakukan terapis wicara dan okupasi lebih dari satu kali dalam seminggu padahal hal itu tidak perlu "menurut terapis" karena yang dibutuhkan anak adalah berlatih dan berinteraksi di lingkungannya, terapis hanya mengarahkan kebiasaan-kebiasaan yang harus dilakukan oleh anak, anak autis tidak bisa dirubah prilakunya dalam waktu yang singkat.

Penulis mendapatkan informasi dari hasil pengamatan dan wawancara langsung dengan narasumber yang berkaitan dengan anak seperti orang tua, guru dan terapis. Dari hasil pengamatan dan wawancara diperoleh data bahwa intervensi yang dilakukan terhadap IM dilakukan melalui terapis yaitu terapi prilaku, terapi wicara, terapi bermain, terapi okupasi, terapi diet. Terapi yang intens dilakukan oleh ahlinya "terapis" adalah terapi wicara dan terapi okupasi sedangkan yang lain dilakukan oleh guru, orang tua dan ahli gizi. Terapi wicara dan okupasi dilakukan di klinik sekolah dengan frekuensi satu kali seminggu, lama terapis adalah 2 jam dibagi menjadi dua yaitu untuk anak 90 menit dan untuk orang tua 30 menit.

Hasil pengamatan dan wawancara menunjukkan informasi bahwa terapi yang diberikan sesungguhnya hanya petunjuk dan awal latihan, selanjutnya orang tua dan gurulah yang melatih anak untuk berprilaku sesuai dengan aturan dan dapat menjadi mandiri.

Terapi bermain dan prilaku dilakukan oleh guru pada saat kegiatan pembelajaran di sekolah, untuk anak autis di lembaga ini setiap guru mendidik 2-3 anak autis 
sehingga anak dapat terlayani dengan baik. Dari hasil wawancara dengan guru diperoleh informasi bahwa yang sulit dalam mengatur/mendidik anak autis adalah membuat dia patuh dan sadar dengan lingkungannya, latihan harus dilakukan secara berulang dan tidak boleh terputus.

Terapi diet berkaitan dengan makanan diperoleh informasi bahwa anak pada awalnya sangat sulit memakan makanan yang disarankan, tetapi dengan kesabaran guru dan orang tua secara bertahap anak menjadi terbiasa. Yang unik di lembaga tempat IM bersekolah adalah setiap hari jumat dilakukan pratik memasak masakan yang sehat untuk anak autis oleh ahli gizi yang diikuti oleh orang tua dan asisten rumah tangga atau pengasuh, dengan dilakukannya praktik atau demo memasak ini diharapkan masakan untuk anak tidak monoton yang akan membuat anak bosan, masakan dibuat semenarik mungkin sehingga anak suka.

Beberapa kemajuan ditunjukkan IM setelah dilakukan terapi terutama pada kemandirian dan interaksi sosial dengan lingkungannya. Tetapi harapan yang terlalu besar dari orang tua membuat terapis dan guru merasa kurang nyaman dengan perlakuan orang tua IM, seharusnya orang tua tidak menyerahkan begitu saja perubahan prilaku anaknya ke terapis atau sekolah tetapi juga keluarga harus dengan sabar melatih anaknya itulah fungsi dari konsultasi pada saat terapis.

\section{SIMPULAN DAN SARAN}

Berdasarkan hasil pengamatan dapat disimpulkan bahwa intervensi yang dilakukan terhadap IM telah berjalan dengan baik. Kemampuan IM pun telah berkembang sesuai dengan harapan guru dan terapis walau pun belum sesuai dengan harapan orang tua. Perlu kesabaran dari semua pihak agar dapat mendukung perkembangan IM, hal yang paling menonjol pada IM adalah ia masih sangat sulit diajak komunikasi atau pun diarahkan untuk melakukan sesuatu terutama dengan orang yang baru dia lihat, dia cenderung acuh dan tidak peduli. Terapis yang diberikan kepada IM diantaranya terapi prilaku, wicara, okupasi, bermain dan diet membuat IM menjadi lebih mandiri dan mau berinteraksi walau pun belum optimal. Terapi harus dilakukan terus menerus baik disekolah maupun di rumah agar perkembangan IM sesuai dengan harapan kedua orang tuanya. 
Ada beberapa hal yang penulis sarankan baik kepada lembaga mau pun kepada orang tua yaitu sebagai berikut.

a. Kepada lembaga sebaiknya ada kunjungan terapis atau tenaga ahli ke rumah anak agar mengetahui sejauh mana program terapis yang diberikan di klinik dan sekolah diterapkan di rumah.

b. Kepada orang tua diharapkan tidak menyerahkan pendidikan anaknya ke guru atau terapis saja tetapi juga ikut mendidik anaknya di rumah sesuai dengan tahapan yang telah diberikan pada saat terapi. Dibutuhkan komunikasi yang baik antara lembaga dan orang tua agar mendukung tumbuh kembang anak.

\section{DAFTAR RUJUKAN}

Hidayat. (2009). Identifikasi dan Asesmen Anak Autis dan Layanan Pendidikannya,. Bandung: Universitas Pendidikan Indonesia.

Hurlock, E.B. (2006). Perkembangan Anak Edisi 8. Jakarta: Erlangga.

Jamaris. (2014). Kesulitan belajar. Jakarta: Ghalia Indonesia.

Rahayu, F. (2014). Kemampuan Komunikasi Anak Autis Dalam Interaksi Sosial (Kasus Anak Autis di Sekolah Inklusi). Skripsi.

Siwi, A.R. \& Anganti, N. R. (2017). Strategi Pengajaran Interaksi Sosial Kepada Anak Autis. Jurnal Indigenous: Jurnal Ilmiah Psikologi, 2(2).

Soeharso. (2011). Pedoman Penanganan dan Pendidikan Autis. Jakarta: Yayasan Pembina Anak Cacat. 